\title{
Basement and Automatic Depth to Magnetic Source Interpretation of Parts of Southern Benue Trough and Anambra Basin.
}

\author{
Eze, M.O ${ }^{1}$. Amoke, A. I' . Dinneya, O. C $C^{2}$. Aguzie, P. C ${ }^{2}$. \\ ${ }^{I}$ (Geology Dept, College of physical and applied sciences/Micheal OkparaUniversity of Agriculture Umudike, \\ Nigeria) \\ ${ }_{2}^{2}$ (Physics Dept, College/ College of physical and applied sciences/Micheal OkparaUniversity of Agriculture \\ Umudike, Nigeria)
}

\begin{abstract}
Aeromagnetic data of sheet 288 and 289 (Igumale and Ejekwe sheet) have been evaluated in order to delineate the magnetic sources and estimate the depths to basement (sedimentary thickness) in the area. SPI technique and analytical signal were used to estimate the magnetic source locations. Visual study of the analytical map shows the presence of igneous intrusions in some part of the area. The output from SPI method and analytical signal are images from which the depths were determined. Maps of the upward continuation emphasized long wavelength basement anomalies. Analytical signal filter revealed near- surface anomalies whose magnitudes range between $0.00009 \mathrm{~m}$ and $3.72295 \mathrm{~m}$. While result from Source parameter Imaging show deep source anomalies of $52.58 \mathrm{~m}$ minimum depth and a maximum depth of $11848.84 \mathrm{~m}$.
\end{abstract}

Keywords: Analytical signal, Spectral parameter Imaging, Depth to the basement, Magnetic anomalies and upward continuation.

\section{Introduction}

Geophysical techniques reveal information about the physical properties of the subsurface. Magnetic method is a geophysical exploration method that its principle is based on taking measurements of the ambient magnetic susceptibility of the surface geology and using the data to determine the distribution of magnetic minerals and the lithology [1]. One of the keys functions of aeromagnetic survey is quantitatively mapping of magnetic source. Quantitative interpretation of potential data aims to estimate three information about the source of geologic interest: the depth, the dimension and the contrast in the relevant physical property [2]. But in many applications, we are often interested in depth more than either dimension or physical property contrast. Thus, different quick methods have been developed, over half a century to estimate the magnetic depth. The automated ways of estimating depths are essential for cost effective interpretation of aeromagnetic surveys [3]. In petroleum exploration the depth to basement is the prime concern [1]. Depth to source interpretation of magnetic field data provides important information on basin architecture for petroleum exploration. Several methods have evolved in the early days of magnetic interpretation simply to estimate the depth of sources from their anomalies without reference to any specific source models [4]. It is better to use more than one reasonable method, together with experienced geologic and geophysical knowledge [2]. In this study the automatic analytical signal method and source parameter imagery were used to estimate the depth to basement at the study area.

\section{Geology of the area:}

The study area lies between latitude $6^{0} 30^{1}-7^{0} 00^{1} \mathrm{~N}$ and longitude $7^{0} 30^{1}-8^{0} 30^{1} \mathrm{E}$. It is located within parts of Southern Benue trough of Nigeria and Anambra basin. Benue trough is part of West African central rift. Sedimentation in the Southern Benue Trough commenced with the deposition of the Asu River group. The Asu River group comprises of the shales, limestones and sandstones lenses of the Abakiliki Formation in the Abakiliki area and the Mfasoming limestone in the calabar flank [5]. [6] also reported some pyroclastic of Aptian-early Albian ages. Awi Formation is the basal, non-calcareous, sandy conglomeratic unit of Asu River Group directly overlying the basement complex (Oban Massif north of calabar). The Cenomanian-Turonian Nkalagu formation and the interfingering regressive sandstones of the Agala and Agbani Formation are resting on the Asu River group. The Ogoja sandstone, the basal aspects of the Asu River Group directly overlying the basement complex have been characterised as consisting of conglomerates and arkosic sandstones in both Ikon and ogoja areas ([7], [8]. The Eze- Aku Group: The "Eze-Aku Group" includes all the stratigrphic units deposited in the late Cenomanian to Turonian in the southern Benue Trough and in the southern parts of the central Benue Trough [9]. These comprises of Eze-aku shales and the correlative units, the Konshisha Group, Amaseri sandstone, Nkalagu Limestone, the Igala sandstone and the Igumale sandstone. The Igumale formation 
unit is a lateral equivalent of the makurdi Formation based on stratigraphic position. The Awgu Formation lies within the southern segment of the trough. It conformably overlies the facies of the Eze aku Group. The succession commonly consists of the shale, sandstone and limestone. The age of Awgu formation span from late Turonian through Coniacian to early Santonian has been suggested by [9]. The age of the Agbani Formation is thought to be largely same as for the Awgu formation.

Following Mid-Santonian tectonism and magmatism, depositional axis in the Benue Trough was displaced westward resulting in subsidence of the Anambra basin [9]. Being a related structure that developed after the compressional stage, they implied that it was logical to include the Anambra basin in the Benue Trough. Nwajide [9], showed that the Anambra basin is a distinct and well demarcated lithostratigraphic entity overlying the Southern Benue Trough and is in turn overlain in its southern part by the Niger Delta Basin. The lithostratigraphic units that filled the Anambra Basin have been divided into two groups: the Nkporo group and the coal measures [9] overlie the Nkporo shale. This consists of fine grained sand, carbonaceous shales and coal with the thickest seam of $1 \mathrm{~km}$ typifying a transitional environment. Its type locality is the Enugu Cuesta. The Ajali Sandstone (Middle coal measures) overlies the Mamu Formation conformably. The Nsukka Formation (Upper coal measures) is the youngest formation from this cycle consisting of interdigitations of very finegrained sandstones, dark shale and coal indicating a parallic environment of Maastrichtian to Paleocene age. Fig 1 is the geology of the area.

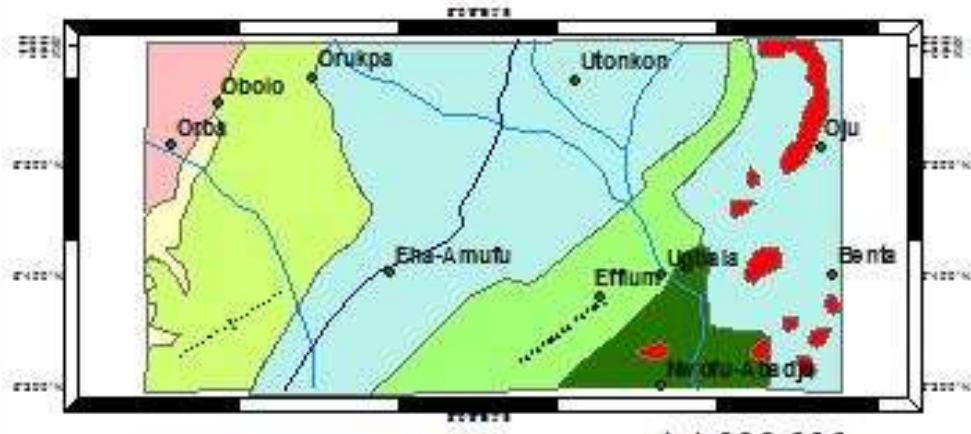

$1: 1,000,000$

\section{Legend}

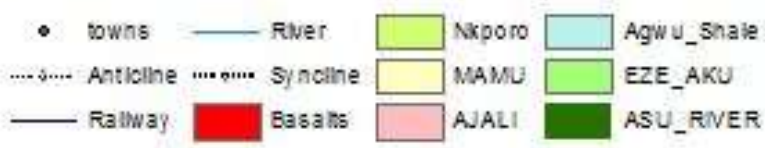

\section{Fig. 1: Geology of the area.}

\section{MATERIAL AND METHODS}

Two sheets of aeromagnetic data were procured from National Geological Survey Agency, Abuja. (Sheet 288 and 289).The aeromagnetic data were obtained as part of the nationwide aeromagnetic survey sponsored by National geological Survey Agency of Nigeria. The magnetic data recording was done with 0.1 second interval. The data were acquired along a series of NW-SE flight line with a spacing of $500 \mathrm{~m}$. In this study the automatic analytical signal method and source parameter imagery were used to estimate the depth to basement at the study area.

Magnetic survey data in the grid form may be interpreted rapidly for source positions and depth by source parameter imagery and analytical signal. The procedures employed in this research include: 
1. Production of Total Magnetic Intensity (TMI) map of the study area in colour aggregate using Oasis Montaj software 6.4.2.

2. The total magnetic intensity map are contoured at 10gamma (nT) interval

3. Computing the Analytical signal using the horizontal Derivatives (DX, DY) and Vertical derivative (DZ) to determine the shallow depths of the anomalies.

4. Computing the SPI using the horizontal Derivatives (DX, DY) and Vertical derivative (DZ) to determine depth to the basement.

5. Computing of upward continued map to $2 \mathrm{~km}, 3 \mathrm{~km}$ and $5 \mathrm{~km}$ depth.

\section{1: GRIDDING:}

In Nigeria, aeromagnetic data are acquired at 500m. Therefore, a $100 \mathrm{~m}$ cell size was used in gridding the data. The bi-directional method of gridding was employed. Bi-direcctional interpolation is commonly applied to grid airborne data. The data is on the scale of 1: 100,000.

\section{2: Analytical signal:}

The Analytical signal present magnetic anomaly information independence of the inclination of the earth's inducing field so that anomalies are positive and sit directly above their sources [10]. Analytical signal derivative is independent of strike, dip, magnetic declination, inclination and remnant magnetization [4]. The analytical signal is a function that relates to the magnetic fields by their derivatives. The 3D analytical signal A of a potential field anomaly

$:|A(x, y)|^{2}=\left(\frac{\delta M}{\delta x}\right)^{2}+\left(\frac{\delta M}{\delta y}\right)^{2}+\left(\frac{\delta M}{\delta z}\right)^{2}$

Where $\mathrm{M}=$ magnetic intensity, Analytical signal map is useful as a type of reduction to the pole, as they are subject to the instabilities that occur in transformations from low latitudes [11]. The application of analytic signals to magnetic interpretation was pioneered by [12] for 2D case, primarily as a tool to estimate depth and position of sources. More recently the method has been expanded to 3D problems as a mapping and depth-tosource technique and as a way to learn about the nature of the causative magnetization. The amplitudes of the analytic signal is simply related to amplitudes of magnetization which could be easily derived from the three orthogonal gradients of the total magnetic field.

\section{3: SOURCE PARAMETER IMAGING (SPI) or SPITM (Thurston and Smith, 1997):}

SPI $^{\mathrm{TM}}$ stands for Source Parameter Imaging, trademarks of Geoterrex. SPI method [13] estimates the depth from the local wavenumber of the analytical signal [14]. SPI is a procedure for automatic calculation of source parameters from gridded magnetic data. The depth estimates obtained will depend on the model assumed. SPI method generally assumes a step-type source model. An advantage of the SPI method is that the depths can be displayed on an image. It uses not only the magnitude of the analytical signal but also the phase. The basics are that for the peaks of the wavenumber define the inverse of the depth. Thus, depth is given by this expression:

$$
\begin{aligned}
& \text { Depth }=\frac{1}{K_{M A X}}=\frac{1}{\left.(\sqrt{(\partial T i l t / \partial x})^{2}+(\partial T i l t / \partial y)^{2}\right)_{M A X}} \\
& \text { Tilt }=\arctan \left(\frac{\partial T / \partial Z}{(\partial T / \partial x)^{2}+(\partial T / \partial Y)^{2}}\right)=\arctan \left(\frac{\partial T / \partial z}{H G R A D}\right)
\end{aligned}
$$

Where $\mathrm{K}_{\max }$ is the peak value of the local wavenumber over the source (horizontal gradient of Tilt derivative). This method assumes either a 2D sloping contact or a 2D dipping thin-sheet model and is based on the complex analytic signal.

\section{4: UPWARD CONTINUATION:}

The transformation of potential data measured on one surface to some higher surface is called upward continuation [15]. Upward continuation is a mathematical technique that projects data taken at one elevation to a higher elevation. Potential field obey Laplace's equation and thus permits us to determine the field over an arbitrary surface if the field is known completely over another surface and no masses are located between the two surfaces [4]. Upward interpretation is useful in the interpretation of magnetic anomaly fields over an area 
like the study area containing many near-surface magnetic sources like intrusions [16]. The equation of the wavenumber domain filter to produce upward continuation is simply

$: F(\omega)=e^{-h \omega}$

Where $\mathrm{h}$ is the continuation height. This function decays steadily with increasing wavenumber, attenuating the higher wavenumbers more severely. Thus, producing maps in which more regional features predominate [4] see fig. $3,4 \$ 5$.

\section{3: Discussion and results:}

The total magnetic intensity of the study area ranges from Minimum value of $\mathbf{- 7 6 . 8 n T}$ to the Maximum value of 108.6nT (Fig. 2). The map shows an acute variation in the magnetic intensity, indicating variations in either lithology or basement topography. The variations in the magnetic intensity are represented by different colours in the map. The colour scheme, in the figure, indicates magnetic low as blue and highs as pink. The deeper heterogeneity of the earth's crust are represented by smooth magnetic contour on the total magnetic intensity map (TMI) in fig. 2, While the smaller and more local sources account for sharper anomaly shapes of more restricted areal extent[17]. The concentrations of high wavelength anomalies (regionals) are on the north western and south western parts of the study area. The rest parts of the study area are concentrated by low wavelength anomalies from the shallow features. These high magnetic intensity values are caused probably by near surface igneous and crystalline basement rocks. The closely spaced, linear sub-parallel orientation of contours from the north western part suggests the possibility of faults or local fractured zones passing through these areas.

The contact between the Anambra basin and Southern Benue Trough is clearly defined by general change in orientation of the magnetic contour (Fig. 2), the contour interval is $5 \mathrm{nT}$.

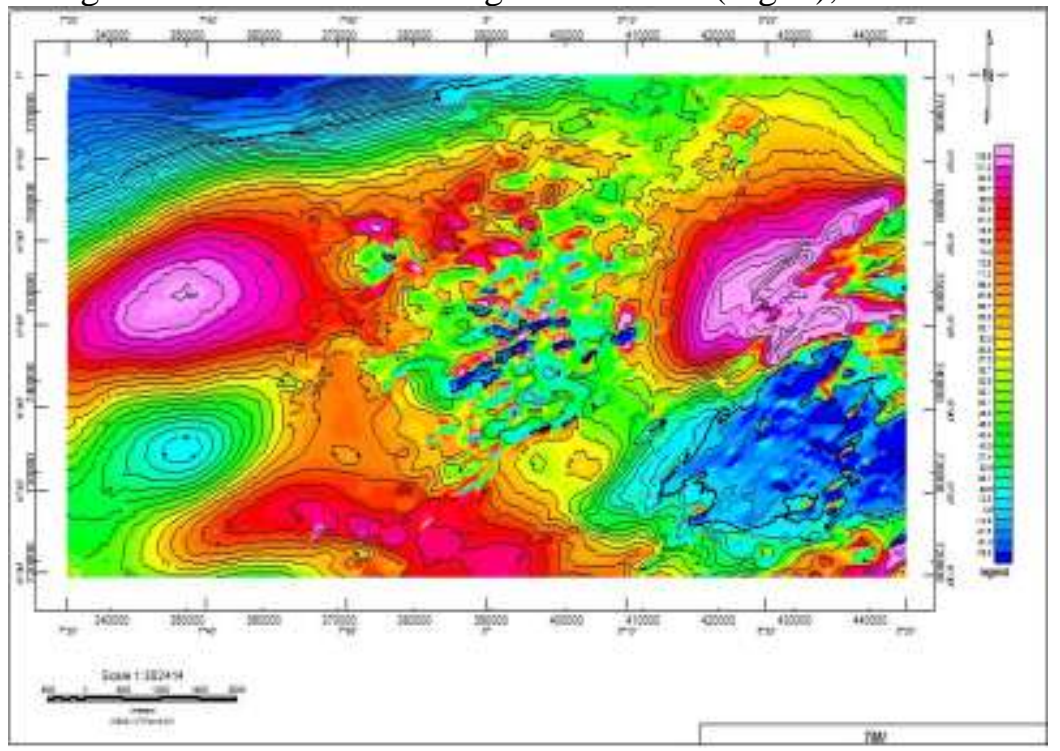

Figure 2: Total Magnetic Intensity.

With analytic signal method, it is now possible to isolate weak anomalies resulting from the subdued magnetic sources occurring within sedimentary strata from magnetic response from the basement. Fig. 7 map was generated from the total Magnetic intensity by application of analytical signal filter, it revealed near- surface anomalies whose magnitudes range between 0.00009 and 3.72295 (Table 1). The amplitude of the analytical signals centred on the peak of the shallow magnetic sources (Fig. 7). The anomalies in the analytic signals are clearer and sharpened because many of the obscured anomalies are now brought to focus. Visual study of the map shows presence of igneous intrusive rocks in the central and northeastern part of the area.The intrusive bodies around Igumale, Oju, Benta, Ubala are well defined in this map. Analytical signal amplitudes peak on the magnetic sources edges ([12], [18], and [19]). The depth to the edges of the lithological units was delineated using the analytical signal amplitudes. Regions with high amplitude outcrops are shown in pink and at shallow depths, while the low amplitude values indicated in blue colour represent the deepest depth to source. Regions with magnetic rock intruding into sedimentary Formations having medium amplitudes are shown in green, 
yellow and red. Maximum amplitude occurs in the areas that have experienced igneous intrusions and is within the Southern Benue Trough basin.

UPWARD CONTINUATION FOR BASEMENT ANALYSIS: It is well-known that the upward continuing field data progressively reduces the effect of shorter-wavelength information [20]. The Total magnetic intensity map was upward continued to elevation of $2 \mathrm{~km}, 3 \mathrm{~km}$ and $5 \mathrm{~km}$ to smoothen and enhanced the more regional basement anomalies. Comparison of the maps to the total magnetic intensity map clearly illustrates how the high wavenumber components of the observed field have been effectively removed by the continuation process [16]. Not much change was observed in the $2 \mathrm{~km}$ upward continuation but $3 \mathrm{~km}$ and $5 \mathrm{~km}$ results are conspicuous (fig. 6). It is a way to enhance the large scale (usually deep) features in the survey area. The shallow intrusive signatures on the Southern Benue trough were all filtered out leaving behind the basement anomalies. The positive and negative anomalies on the TMI map were still showing on the Upward continued maps. Two positive anomalies (pink) on the southern western and eastern portions of the study area. The upward continuation maps indicate that the positive anomaly at the southern portion of the study is deeper than the southern portion anomaly on the study area.

The negative anomaly did not change much. The positive anomaly of intensity range between $-28.7-74.4 \mathrm{nT}$ (pink) in the $5 \mathrm{~km}$ upward continued map appear clearer than on the $3 \mathrm{~km}$ upward continued map. The intensity range is between $82.2 \mathrm{nT}$ and $-35.4 \mathrm{nT}$ (pink) in the $3 \mathrm{~km}$ map. The positive anomaly lies in the area underlain by Eze-Aku formation rocks and geographically located on northwest part of Nwofu Abadja area. The positive and negative anomalies on the southeastern portion of the study area lie in the area underlain by dolerite intrusion (southern Benue trough) (Fig.1). The negative anomaly must have resulted from hydrothermal fluids which can deposit less magnetic materials in the fractured rock (Fig. 5). The positive anomaly with weakly magnetic signatures is at the northwestern zone and lie in area underlain by Anambra basin Formations. It could be from the weakly magnetic ferruginized ironstones.

Table 1: Statistic Report of source depth value estimate using Analytical signal.

\begin{tabular}{|l|l|}
\hline Statistics Information & Depth to source $(\mathbf{M})$ \\
\hline MINIMUM DEPTH VALUE & 0.00009416 \\
\hline MAXIMUM DEPTH VALUE & 3.72295165 \\
\hline MEAN VALUE & 0.03437328 \\
\hline STANDARD DEVIATION: & 0.088795 \\
\hline ARITHMETIC SUM: & 21182.43 \\
\hline
\end{tabular}

SOURCE PARAMETER IMAGERY ANALYSIS For the 182178 SPI values, the maximum depth $52.58 \mathrm{~m}$ value of the following table is the statistic report of depth to source values estimated using SPI imaging technique. The light blue to deep blue colors at the end of the legends shows areas of thicker sediments or deep lying magnetic bodies. The upper colors (pink and red) at the other end of the SPI legends shows areas of shallower sediment or near surface lying magnetic bodies. Depth to the basement profile map and depth to basement map (Fig. 8 \& 9) generated using the SPI technique show that the region that have deepest basement depth is area around Nkalagu- Owo-Eha Amufu axis in the southwestern portion of the area and around Igumale at the northern part of the area, within Benta area and places laying at the western part of the area towards the Aimeke in Benue state of Ngeria. The depth to the basement within the southern Benue Trough sediments of Agwu Formation, Eze-Aku Formation and Asu River group is of intermediate and shallow solutions. Shallow solution is also dominant in the southern part of Enugu and within Obolo areas at the north western portion of the area (Fig. 9). Table 3 shows the comparative values of deep basement depth with the shallow source depth to the basement of the analytical signal.

Table 2: Statistic Report of source depth value estimate using Source parameter sources.

\begin{tabular}{|l|l|}
\hline Statistics Information & Depth to source ( M) \\
\hline $\begin{array}{l}\text { MINIMU DEPTH VALUE } \\
\text { M DEPTH VALUE }\end{array}$ & -11848.84244 \\
\hline $\begin{array}{l}\text { MAXIMU } \\
\text { MEAN VALUE }\end{array}$ & -52.58228996 \\
\hline $\begin{array}{l}\text { STANDA DEVIATION: } \\
\text { RD SUM: }\end{array}$ & -560.1243178 \\
\hline \begin{tabular}{l} 
ARITHME \\
TIC $\quad-542.389115$ \\
\hline
\end{tabular} \\
\hline
\end{tabular}


Table 3: comparative depth estimates from selected locations in the study area.

\begin{tabular}{|l|l|l|l|}
\hline \multicolumn{2}{|l|}{ Locations (UTM). } & SPI Depth $(\mathrm{m})$ & Analytical signal(m) \\
\hline Longitude & Latitude & & \\
\hline & 401243.3 & -586.845 & 0.01933 \\
& 750136.3 & & \\
\hline & 374677.5 & -1740.833 & 0.01052 \\
& 767527.3 & & \\
\hline & 391355.3 & -206.875 & 0.00157 \\
& 721009.3 & & 0.41131 \\
\hline & 393848.7 & -132.581 & 0.01152 \\
\hline & 747123.7 & & \\
\hline
\end{tabular}

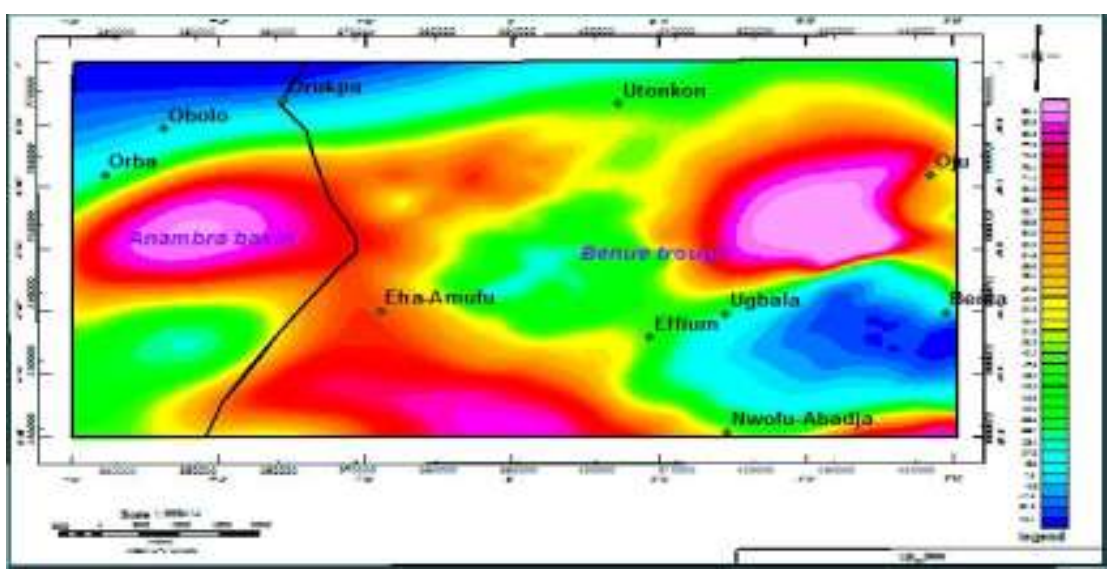

Fig. 3: upward continued to $2 \mathrm{~km}$. (the solid line that demarcates the southern Benue trough and Anambra basin is overlain).

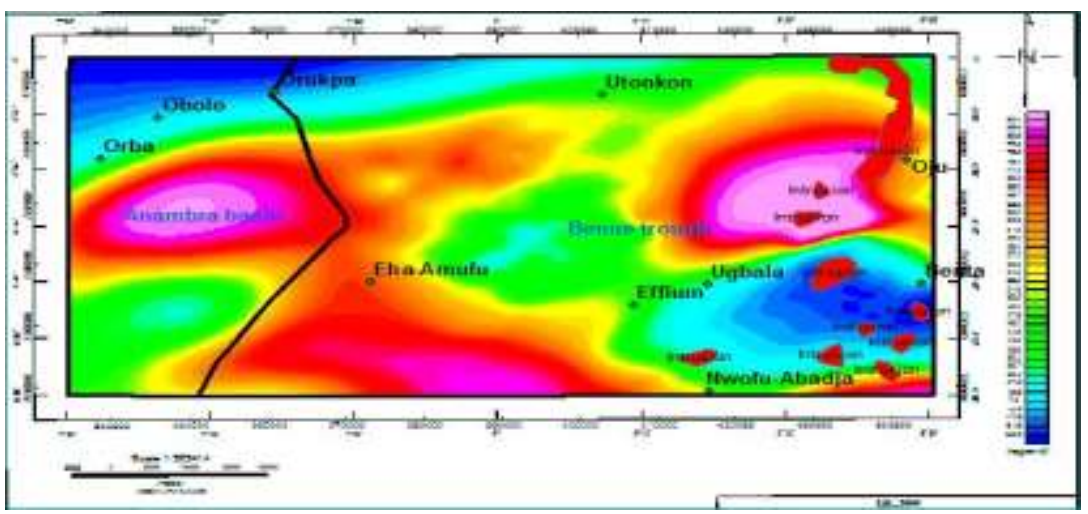

Fig. 4: upward continued to $3 \mathrm{~km}$. (The solid line that demarcates the southern Benue Trough and Anambra basin is overlain).

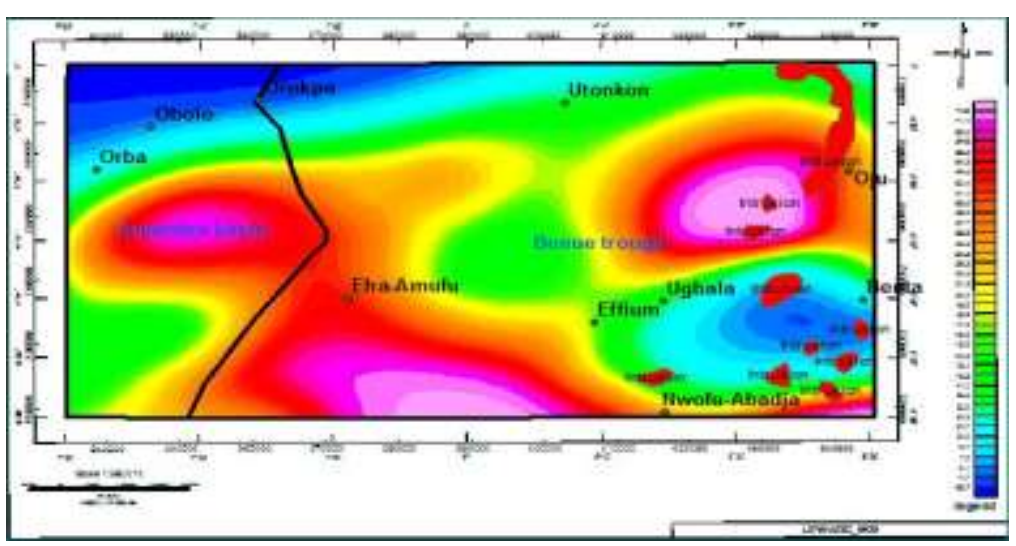


Figure. 5: upward continued to $5 \mathrm{~km}$. (the solid line that demarcates the southern Benue trough and Anambra basin is overlain).

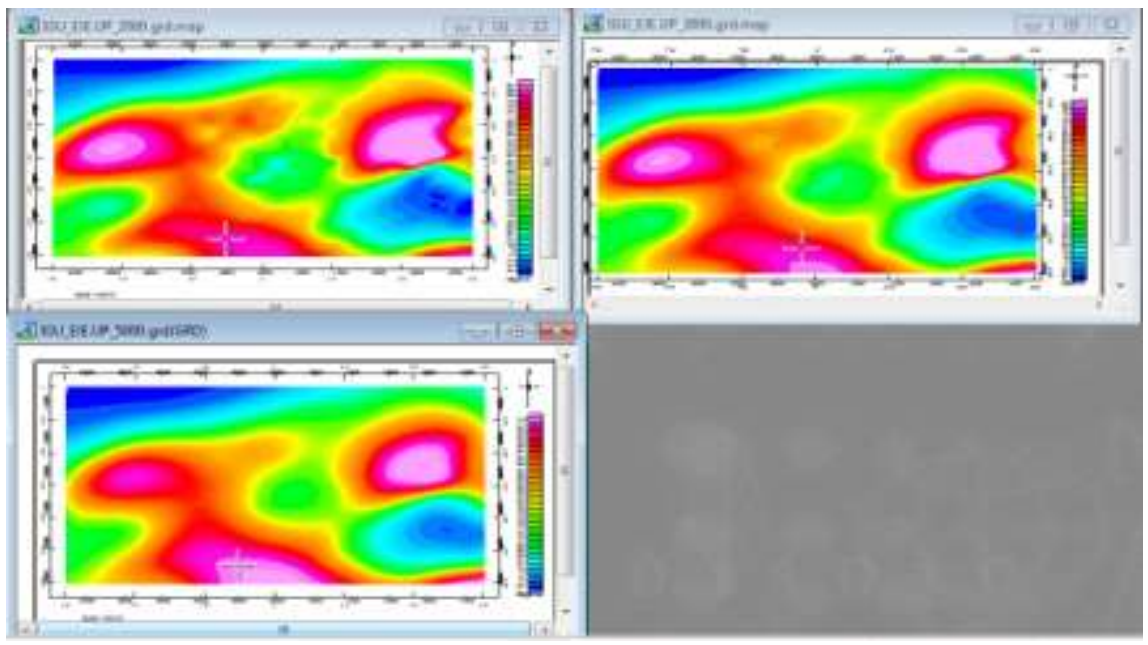

Figure .6: comparative of the $2 \mathrm{~km}, 3 \mathrm{~km}$, and $5 \mathrm{~km}$ upward continued maps.

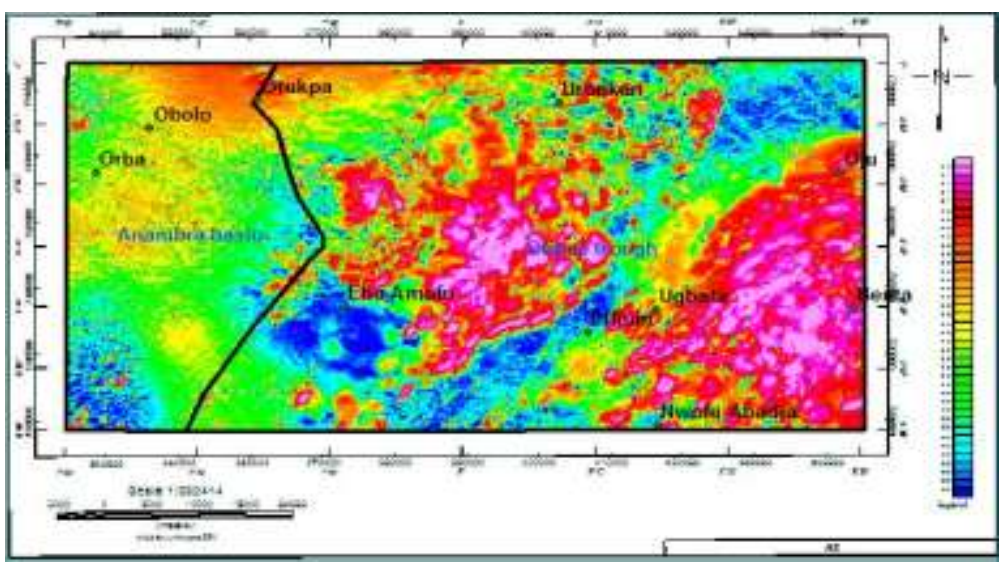

Figure. 7: Analytical signal map. (The solid line that demarcates the southern Benue Trough and Anambra basin is overlain).

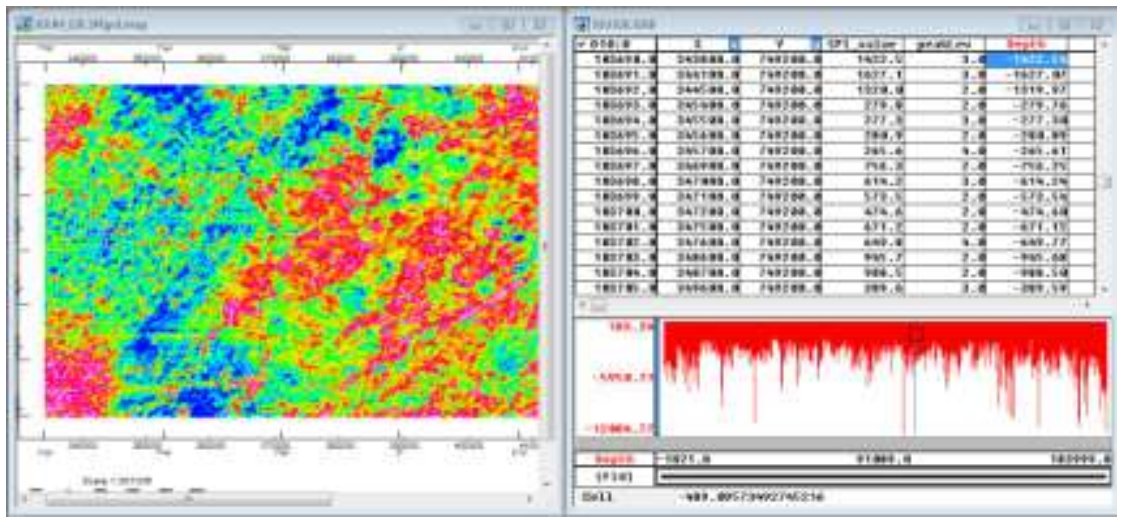

Figure 8: the spi depth profile map. 


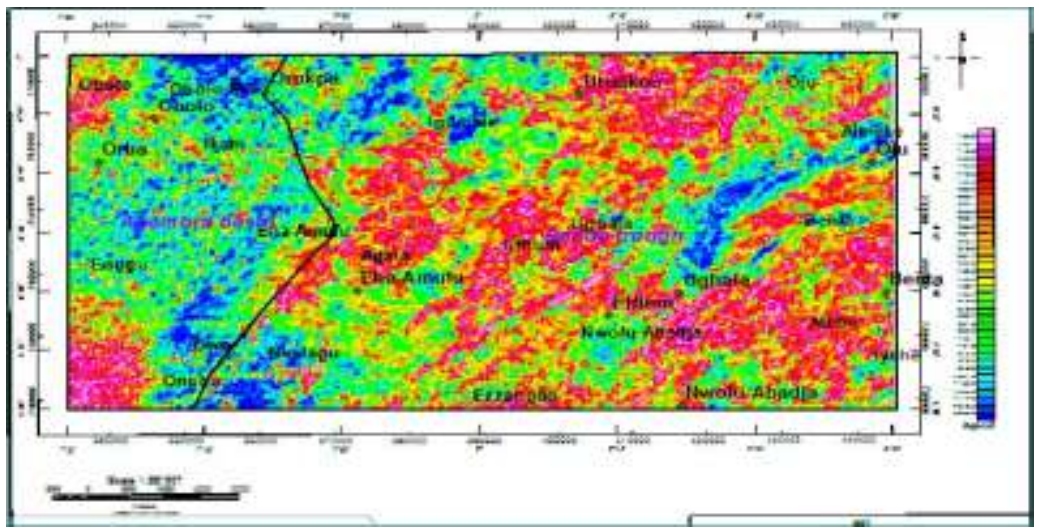

Fig 9: Source Parameter Imaging map

\section{CONCLUSION}

Map of spectral source imaging reveals the basement topography or the depths to the deep magnetic sources of the study area, while the analytical signal map reveals locations of short wavelength anomalies. Maximum amplitude occurs in the areas that have experienced igneous intrusions. The shallow magnetic anomalies are associated with intra- sedimentary intrusions. The upward continued anomalies must result from the relatively deep structures and represent a valid regional field for the area. The intrusive rocks on the southern Benue Trough indicate high temperatures and this makes it impossible for hydrocarbon to occur there. The upward continuation maps indicate that the positive anomaly at the central portion of the study is deeper than the southern portion anomaly on the study area.

\section{Acknowledgements}

The authors wish to appreciate Nigeria Geological Survey Agency for releasing the airborne data used for this study.

\section{REFERENCES}

[1] W.M., Telford, L.P. Geldart \& R.E. Sheriff, applied geophysics ( Cambridge University press, 1990.

[2] L. Xiong, "On the use of different methods for estimating magnetic depth." The Leading Edge, 22(11), 1090-1099, 2003.

[3] Interepid Geophysics user manual estimating Magnetic Depth - Overview (2006).

[4] C. Reeves, aeromgnetic surveys, principles,practice and interpretation.(Geosoft, 2005)

[5] S.W., Peters, Biostratigraphy of upper Cretaceous Foraminifera of the Benue Trough, Nigeria. J. Foram Res., 10, 191- $204,1982$.

[6] .A. Ojoh, The Southern part of the Benue Trough (Nigeria) Cretaceous stratigraphy, basin analysis, paleo- oceanography and geodynamic evolution in the equatorial domain of the south Atlantic, NAPE Bull.7, 131-152, 1992.

[7] A.B., Uzuakpunwa, Petrography differentiation of tectonically controlled Cretaceous sedimentary cycles south eastern Nigeria. Sedimentary Geology, 17, 234 - 245. (1980).

[8] S.W. Peters, C.S., Okereke, and C.S., Nwajide, Geology of the Mamfe Rifts, Southeastern Nigeria 1987.

[9] C.S, Nwajide, geology of nigeria sedimentary basins. (CSS press 2013),

[10] W.R., Roest, J.,Verhoej, and Pilkingtonm, Magnetic interpretation using 3D analytical signal, Geophysics 57(1), 1992, 116125.

[11] D. O, Marcotte, R. S. Smith and M. A. Valle, Gridding aeromagnetic data using longitudinal and transverse horizontal gradients with the minimum curvature operator. Leading edge 24 (2), 142-145, 2005.

[12] M.N., Nabighian, The a nalytic signal of two dimensional magnetic bodies with polygonal cross-section: its properties and use for automated anomaly interpretation. Geophysics, v. 37, $507-517,1972$.

[13] J. B., Thurston, and R.S., Smith Automatic conversion of magnetic data depth, dip, susceptibility contrast using SPI ${ }^{\mathrm{TM}}$ method: Geophysics, 62, 807-813. 1997.

[14] R. S., Smith, J. B., Thurston, T. F. Dai and I. N., Macleod, SPI ${ }^{\mathrm{TM}}$ - the improved source parameter imaging method $^{1}$, SGeophysical Prospecting, 46, 1998. 141-151. (1998)

[15] M.B., Dobrin, and C.H Savit, introduction to geophysical prospecting (MC Hill international Edition 1988).

[16] P. Keary, M. Brooks and I. Hill, an introduction to geophysical exploration (Blackwell science, 2002)

[17] E. S., Akanbi and W. E, Mangset Structural trends and spectral analysis of the residual magnetic field of Naraguta area, North central, Nigeria. Indian journal of science and Technology. Vol. 4, No. 112011.

[18] M.N. Nabighian Towards a three dimensional automatic interpretation of potential field data via generalized Hilbert transform Fundamental relations. Geophysics, Vol.47, 780-786. (1984):

[19] I. N., MacLeod, K. Jones, and T. F. Dai, 3-D analytical signal in the interpretation of total magnetic field data at low magnetic latitudes: Exploration Geophysics, 24, 1993. 679-688.

[20] L. Ilkka and T. Karinen Tilt derivative multiscale edges of magnetic data. The leading edge vol. 29. No. 1. 2010. 